\title{
Measurement of $\mathrm{NO}_{x}$ and $\mathrm{NO}_{y}$ with a thermal dissociation cavity ring-down spectrometer (TD-CRDS): instrument characterisation and first deployment
}

Nils Friedrich et al.

Correspondence to: John N. Crowley (john.crowley@mpic.de)

The copyright of individual parts of the supplement might differ from the CC BY 4.0 License. 

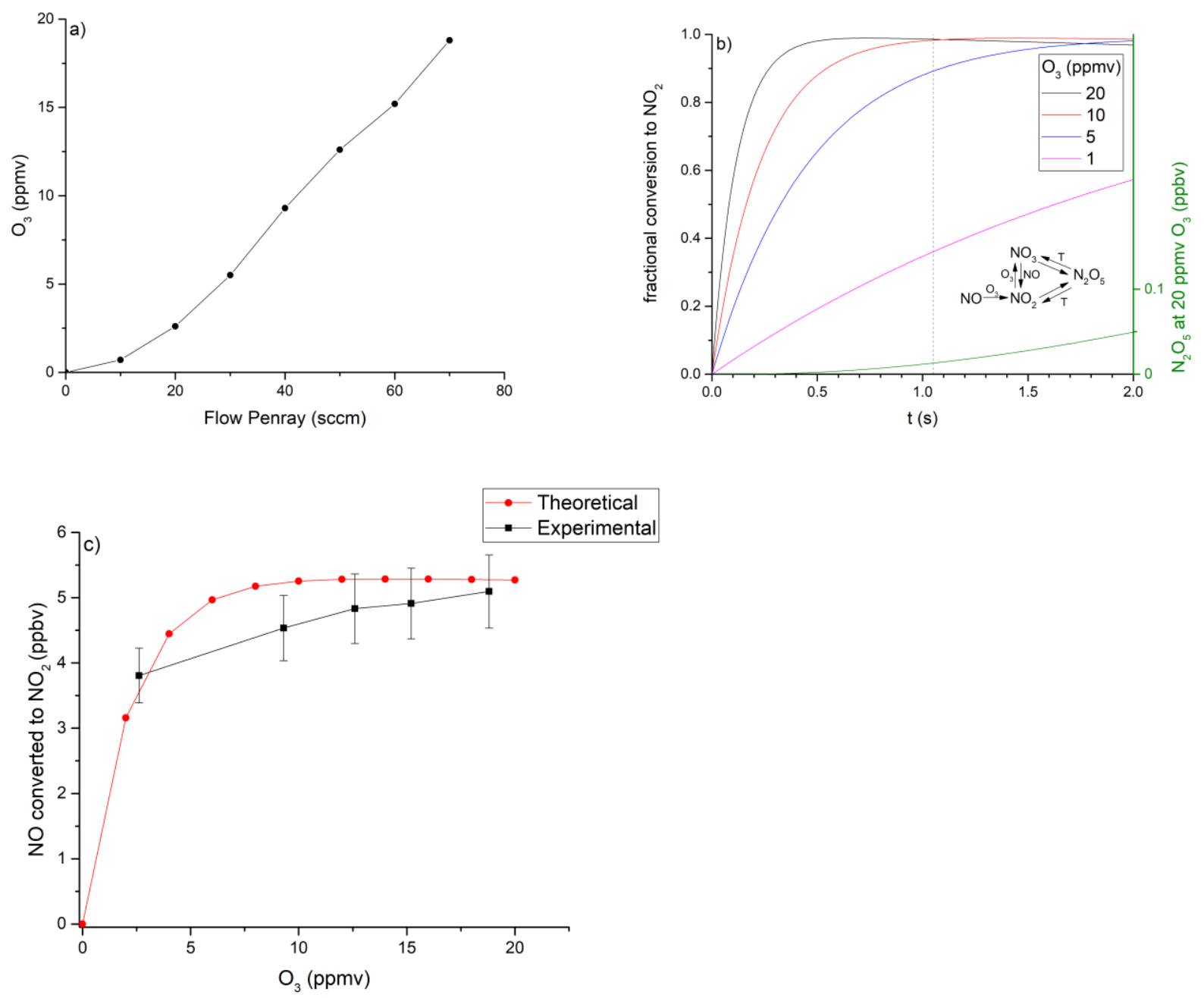

Figure S1: Optimisation of $\mathrm{NO}$ to $\mathrm{NO}_{2}$ conversion via the addition of $\mathrm{O}_{3 .}$ a) Ozone generated by passing synthetic air over the Pen-Ray lamp as a function of the flow rate. $b$ ) Numerical simulation of the fractional NO conversion as a function of reaction 5 time and a chemical scheme showing reactions included in the model. High concentrations of $\mathrm{O}_{3}$ can lead to the formation of significant amounts of $\mathrm{N}_{2} \mathrm{O}_{5}$ (50 pptv at 20 ppmv $\mathrm{O}_{3}$ and 2 s reaction time). c) Conversion of 5.3 ppbv $\mathrm{NO}$ to $\mathrm{NO}_{2}$ as a function of $\mathrm{O}_{3}$ in $1.05 \mathrm{~s}$ reaction time. Both laboratory results and predictions of a numerical simulation are shown. Quantitative conversion is achieved for $\mathrm{O}_{3}$ concentrations above 15 ppmv. The error bars indicate total overall uncertainty. 

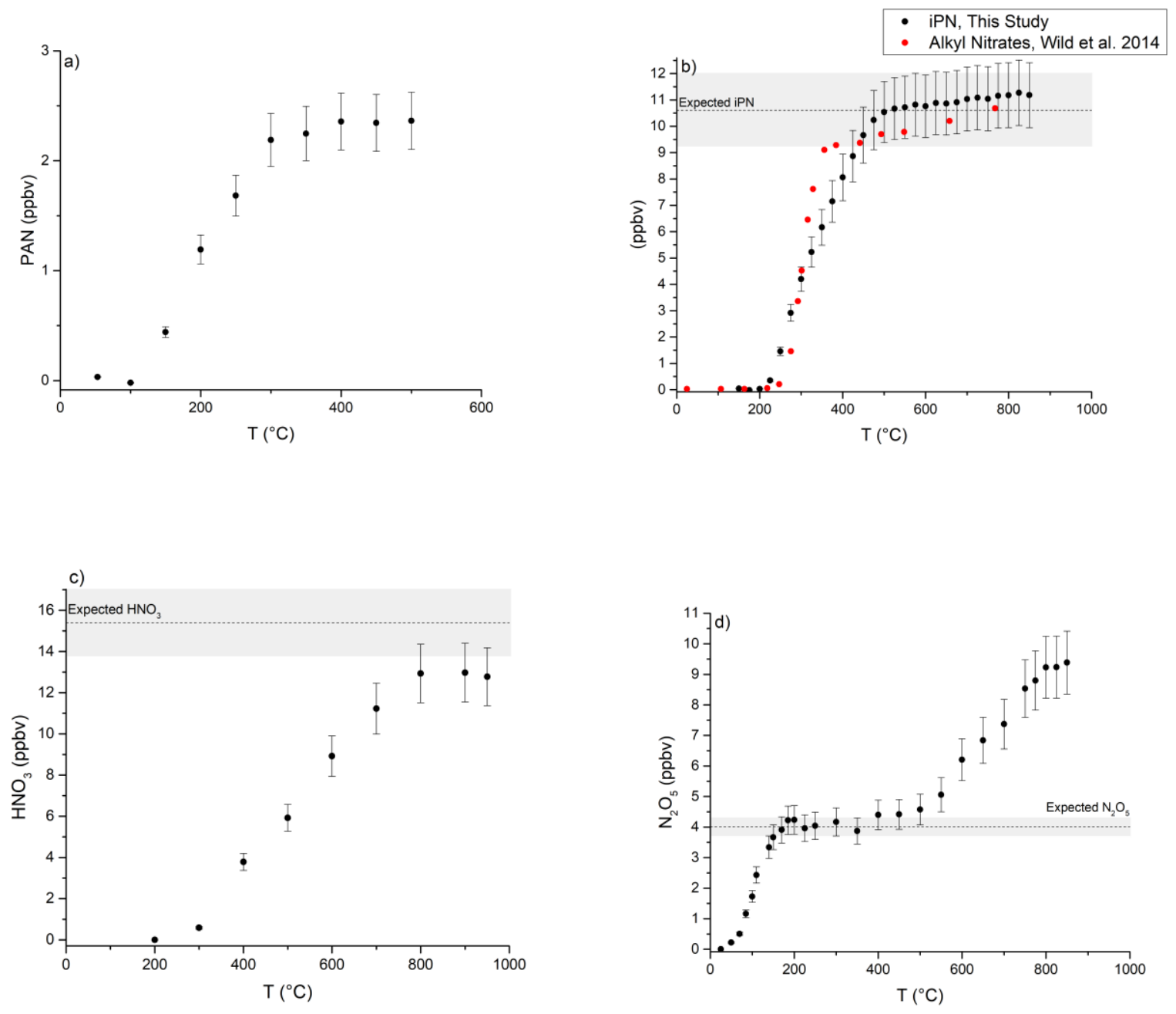

Figure S2: Absolute thermograms of PAN (a), iPN (b), $\mathrm{HNO}_{3}(c)$, and $\mathrm{N}_{2} \mathrm{O}_{5}(d)$. Error bars represent the measurement 5 uncertainty (see Sect. 2.2). Shaded areas show the estimated uncertainty ranges for the expected $\mathrm{iPN}$ and $\mathrm{HNO}_{3}$ concentrations, based on errors during sample preparation and gas stream dilution. Within combined uncertainties we observe quantitative conversion of PAN, iPN, $2 \mathrm{x} \mathrm{N}_{2} \mathrm{O}_{5}$ and $\mathrm{HNO}_{3}$ to $\mathrm{NO}_{2}$ at the TD-CRDS set temperature of $850{ }^{\circ} \mathrm{C}$. $(b)$ also includes data points for an alkyl nitrates mixtures from Wild et al. (2014), to illustrate the continuous increases in signal above $400{ }^{\circ} \mathrm{C}$.

Wild, R. J., Edwards, P. M., Dube, W. P., Baumann, K., Edgerton, E. S., Quinn, P. K., Roberts, J. M., Rollins, A. W., Veres, P. 10 R., Warneke, C., Williams, E. J., Yuan, B., and Brown, S. S.: A measurement of total reactive nitrogen, NOy, together with $\mathrm{NO}_{2}, \mathrm{NO}$, and $\mathrm{O}_{3}$ via cavity ring-down spectroscopy, Env. Sci. Tech., 48, 9609-9615, doi:doi:10.1021/es501896w, 2014 
a)

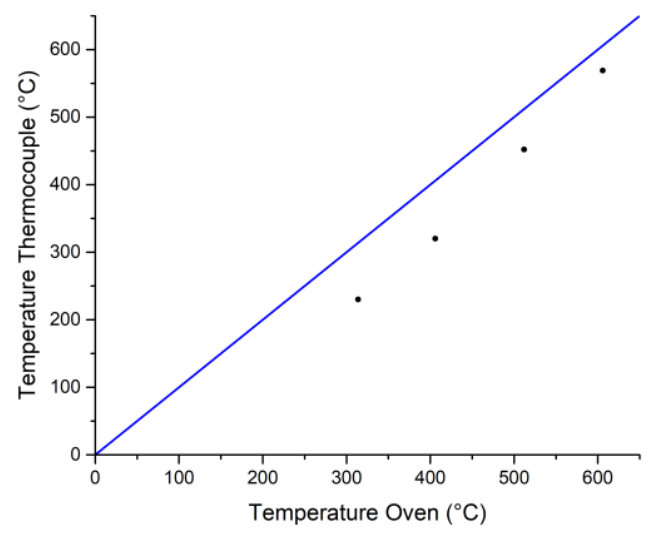

b)

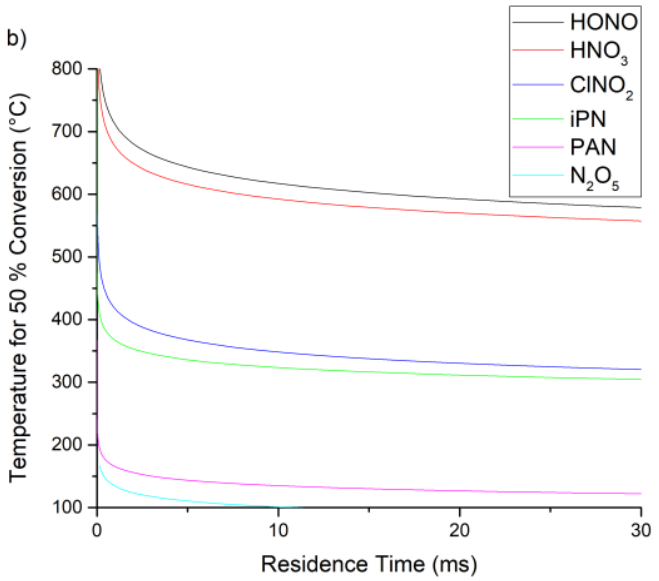

c)

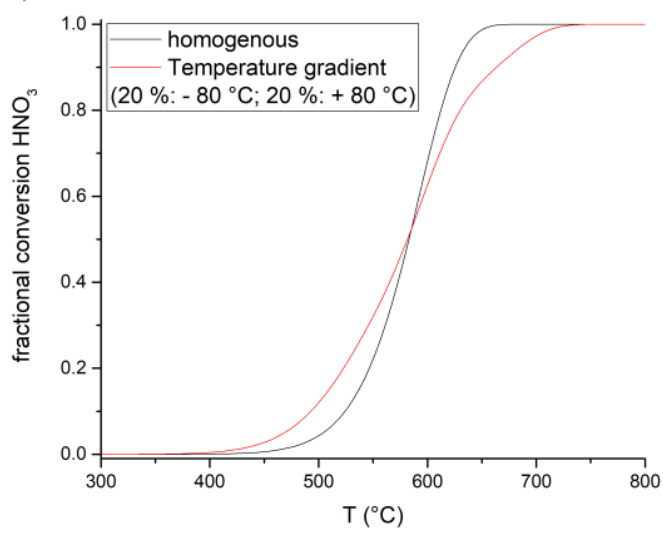

5 Figure S3: a) Plot of temperature from the internal reading of the TD-oven and a thermocouple located in the gas stream. The blue line shows a 1:1 correlation. b) Calculated threshold temperature for 50\% conversion of $\mathrm{N}_{2} \mathrm{O}_{5}, \mathrm{PAN}, \mathrm{PN}, \mathrm{ClNO}_{2}, \mathrm{HNO}_{3}$ and $\mathrm{HONO}$ to $\mathrm{NO}_{\mathrm{x}}$ relative to the residence time in the heated inlet and based on kinetic parameters of their thermal dissociation (see Sect. 3.1.8). For $\mathrm{HNO}$, the threshold temperature increases by $40{ }^{\circ} \mathrm{C}$ when the residence time decreases from 30 to $10 \mathrm{~ms}$. c) Impact of temperature gradients inside the TD-inlet on the shape of the calculated $\mathrm{HNO}_{3}$ thermogram. The width of the 10 thermogram increases by ca. $100^{\circ} \mathrm{C}$. 


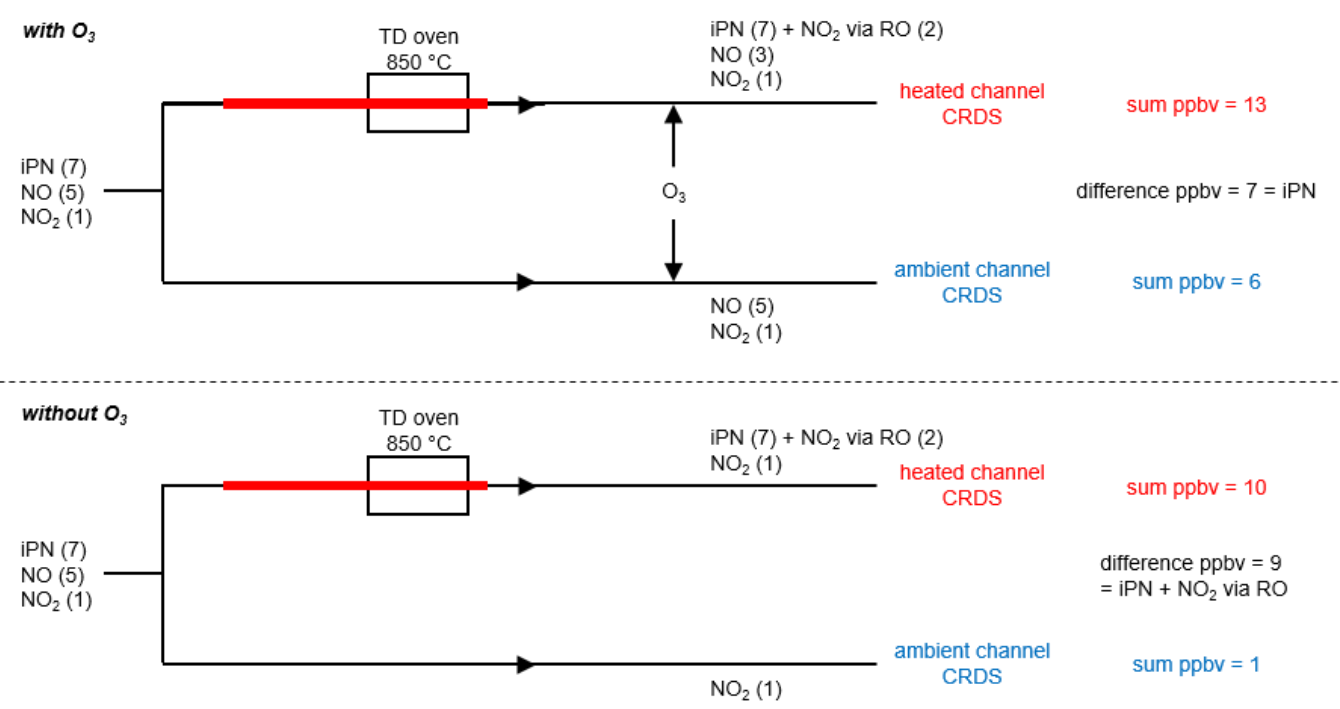

Figure S4: Graphical representation of the bias caused by $\mathrm{RO}_{2}+\mathrm{NO}$ reactions in detecting iPN. In both cases an initial mixing 5 ratio of $7 \mathrm{ppbv}$ iPN is present, along with $5 \mathrm{ppbv} \mathrm{NO}$ and $1 \mathrm{ppbv} \mathrm{NO}$. When passed through the oven the iPN is converted to 7 ppbv $\mathrm{NO}_{2}$ and (in this scenario) 2 ppbv of $\mathrm{NO}$ are converted to $\mathrm{NO}_{2}$ via reaction with $\mathrm{HO}_{2}$. In total 13 ppbv of $\mathrm{NO}_{2}$ are detected in the cavity sampling via the oven. In the cavity at ambient temperature $6 \mathrm{ppbv}$ of $\mathrm{NO}_{2}$ are detected so that a (correct) iPN mixing ratio of $7 \mathrm{ppbv}$ is derived. In the lower part of the figure, the same initial conditions apply, but $\mathrm{O}_{3}$ is not added. The conversion of 2 ppbv $\mathrm{NO}$ to $\mathrm{NO}_{2}$ occurs as above, so that $10 \mathrm{ppbv} \mathrm{NO}_{2}$ are detected when sampling from the oven. The

$10 \mathrm{NO}_{2}$ mixing ratio in the cavity sampling at ambient is $1 \mathrm{ppbv}$, resulting in a derived (incorrect) $\mathrm{NO}_{2}$ iPN mixing ratio of 9 ppbv. 


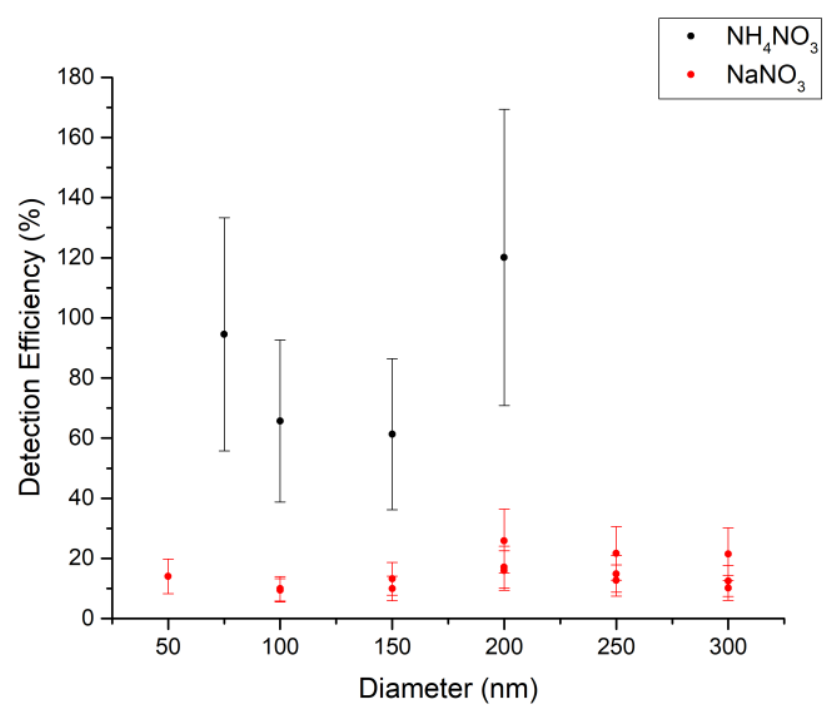

Figure S5: Detection efficiencies of $\mathrm{NH}_{4} \mathrm{NO}_{3}$ and $\mathrm{NaNO}_{3}$ in the TD-CRDS, as a function of particle diameter. The CPC 5 measured particle numbers were converted to mixing ratios and compared to the TD-CRDS. Errors imminent for this method are explained in Sect. 3.1.7. The particle conversion to $\mathrm{NO}_{2}$ is clearly more efficient for $\mathrm{NH}_{4} \mathrm{NO}_{3}$, in direct comparison to $\mathrm{NaNO}_{3}$. 


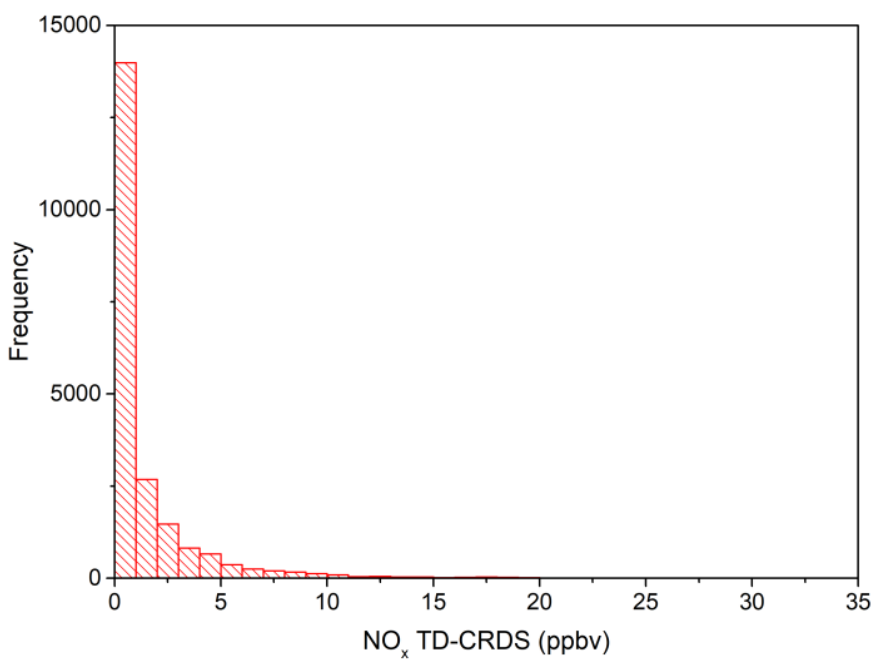

Figure S6: Histogram of the AQABA TD-CRDS $\mathrm{NO}_{x}$ mixing ratios shown in Fig. 10a). $92 \%$ of the $\mathrm{NO}_{\mathrm{x}}$ data points were at mixing ratios below 5 ppbv.

5 
Table S1: Reactions included in the numerical simulations used to generate Fig. S1.

\begin{tabular}{|c|c|}
\hline Reaction & Rate coefficients (Burkholder et al. (2015) \\
\hline $\mathrm{NO}_{2}+\mathrm{O}_{3} \rightarrow \mathrm{NO}_{3}+\mathrm{O}_{2}$ & $1.2 \mathrm{E}-13 * \exp (-2450 / \mathrm{T})$ \\
\hline $\mathrm{NO}+\mathrm{NO}_{3} \rightarrow \mathrm{NO}_{2}+\mathrm{NO}_{2}$ & $1.5 \mathrm{E}-11 * \exp (170 / \mathrm{T})$ \\
\hline $\mathrm{NO}+\mathrm{O}_{3} \rightarrow \mathrm{NO}_{2}+\mathrm{O}_{2}$ & $3.0 \mathrm{E}-12 * \exp (-1500 / \mathrm{T})$ \\
\hline $\mathrm{N}_{2} \mathrm{O}_{5} \rightarrow \mathrm{NO}_{3}+\mathrm{NO}_{2}$ & $\begin{array}{l}\left(\left(\left(2.0 \mathrm{E}-30 *(\mathrm{~T} / 300)^{\wedge}-4.4\right)^{*} \mathrm{M} /\left(1+\left(\left(2.0 \mathrm{E}-30 *(\mathrm{~T} / 300)^{\wedge}-\right.\right.\right.\right.\right. \\
\left.\left.\left.4.4)^{*} \mathrm{M} /\left(1.4 \mathrm{E}-12 *(\mathrm{~T} / 300)^{\wedge}-0.7\right)\right)\right)\right)^{*} 0.6^{\wedge}((1+(\mathrm{LOG} 10((2.0 \mathrm{E}- \\
\left.\left.\left.\left.30 *(\mathrm{~T} / 300)^{\wedge}-4.4\right)^{*} \mathrm{M} /\left(1.4 \mathrm{E}-12 *(\mathrm{~T} / 300)^{\wedge}-0.7\right)\right)\right)^{\wedge} 2\right)^{\wedge-} \\
1)) /(3.0 \mathrm{E}-27 * \exp (10990 / \mathrm{T}))\end{array}$ \\
\hline $\mathrm{NO}_{2}+\mathrm{NO}_{3} \rightarrow \mathrm{N}_{2} \mathrm{O}_{5}$ & $\begin{array}{l}\left(\left(2.0 \mathrm{E}-30 *(\mathrm{~T} / 300)^{\wedge}-4.4\right)^{*} \mathrm{M} /\left(1+\left(\left(2.0 \mathrm{E}-30^{*}(\mathrm{~T} / 300)^{\wedge}-\right.\right.\right.\right. \\
\left.\left.\left.4.4)^{*} \mathrm{M} /\left(1.4 \mathrm{E}-12^{*}(\mathrm{~T} / 300)^{\wedge}-0.7\right)\right)\right)\right)^{*} 0.6^{\wedge}((1+(\mathrm{LOG} 10((2.0 \mathrm{E}- \\
\left.\left.\left.\left.\left.30^{*}(\mathrm{~T} / 300)^{\wedge}-4.4\right)^{*} \mathrm{M} /\left(1.4 \mathrm{E}-12 *(\mathrm{~T} / 300)^{\wedge}-0.7\right)\right)\right)^{\wedge} 2\right)^{\wedge}-1\right)\end{array}$ \\
\hline
\end{tabular}

Burkholder, J. B., Sander, S. P., Abbatt, J., Barker, J. R., Huie, R. E., Kolb, C. E., Kurylo, M. J., Orkin, V. L., Wilmouth, D. 5 M., and Wine, P. H.: Chemical Kinetics and Photochemical Data for Use in Atmospheric Studies, Evaluation No. 18," JPL Publication 15-10, Jet Propulsion Laboratory, Pasadena, http://jpldataeval.jpl.nasa.gov., 2015. 
Table S2: Denuder characterisation

\begin{tabular}{|c|c|c|c|c|}
\hline NO $_{\text {y }}$ species & $\begin{array}{l}\text { RH } \\
(\%)\end{array}$ & $\begin{array}{l}\text { Reference mixing } \\
\text { ratio (pptv) } \\
\quad=\mathbf{I}_{0} \pm \Delta \mathbf{I}_{0}\end{array}$ & $\begin{array}{l}\text { Mixing ratio with denuder } \\
\text { (pptv) } \\
=\mathbf{I} \pm \Delta \mathbf{I}\end{array}$ & $\begin{array}{l}\text { Removal efficiency (\%) } \\
\quad=(\mathbf{R} \pm \Delta \mathbf{R}) \times 100\end{array}$ \\
\hline \multirow[t]{8}{*}{$\mathrm{NO}$} & 0 & \multirow{8}{*}{$37036 \pm 261$} & $0 \pm 43$ & $100.0 \pm 1.0$ \\
\hline & 14 & & $62 \pm 46$ & $99.8 \pm 1.0$ \\
\hline & 28 & & $832 \pm 94$ & $97.8 \pm 1.0$ \\
\hline & 42 & & $7832 \pm 60$ & $78.9 \pm 0.9$ \\
\hline & 55 & & $10391 \pm 65$ & $71.9 \pm 0.9$ \\
\hline & 68 & & $12575 \pm 45$ & $66.0 \pm 0.9$ \\
\hline & 81 & & $13758 \pm 51$ & $62.9 \pm 0.8$ \\
\hline & 97 & & $14220 \pm 74$ & $61.6 \pm 0.9$ \\
\hline \multirow[t]{8}{*}{ iPN } & 0 & \multirow[t]{8}{*}{$20181 \pm 247$} & $0 \pm 22$ & $100.0 \pm 1.0$ \\
\hline & 14 & & $-98 \pm 91$ & $100.5 \pm 1.0$ \\
\hline & 27 & & $-65 \pm 58$ & $100.3 \pm 1.0$ \\
\hline & 41 & & $355 \pm 49$ & $98.2 \pm 0.9$ \\
\hline & 55 & & $303 \pm 41$ & $98.5 \pm 0.9$ \\
\hline & 68 & & $537 \pm 47$ & $97.3 \pm 0.9$ \\
\hline & 81 & & $907 \pm 46$ & $95.5 \pm 0.8$ \\
\hline & 95 & & $1043 \pm 33$ & $94.8 \pm 0.9$ \\
\hline \multirow[t]{2}{*}{$\mathrm{HNO}_{3}$} & 0 & $8224 \pm 214$ & $35 \pm 58$ & $99.6 \pm 2.7$ \\
\hline & 68 & $9104 \pm 173$ & $247 \pm 50$ & $97.3 \pm 3.7$ \\
\hline \multirow[t]{2}{*}{$\mathrm{NO}_{2}$} & 0 & $24259 \pm 211$ & $54 \pm 45$ & $99.8 \pm 1.3$ \\
\hline & 65 & $24164 \pm 225$ & $448 \pm 40$ & $98.1 \pm 1.2$ \\
\hline PAN & 0 & $7575 \pm 93$ & $58 \pm 130$ & $99.2 \pm 2.4$ \\
\hline $\mathrm{N}_{2} \mathrm{O}_{5}$ & 0 & $4179 \pm 230$ & $5 \pm 48$ & $99.9 \pm 7.8$ \\
\hline HONO & 46 & $10000 \pm 61$ & $1521 \pm 47$ & $84.8 \pm 0.9$ \\
\hline $\mathrm{ClNO}_{2}$ & 60 & $2068 \pm 103$ & $521 \pm 141$ & $74.8 \pm 9.2$ \\
\hline
\end{tabular}

Mixing ratios (reference determined in heated inlet with bypassed denuder), standard deviations $(1 \sigma)$ during the averaging intervals and derived denuder removal efficiencies of various $\mathrm{NO}_{\mathrm{y}}$ species, as a function of $\mathrm{RH}$ and as presented graphically

5 in Fig. $6 . R=\left(I_{0}-I\right) / I_{0} . \Delta R$ was determined by error propagation. 